\title{
Influence of Organic, Inorganic and Organo-Mineral Fertilizers on Yield and Quality of Sweet Potato (Ipomoea batatas)
}

\author{
${ }^{1}$ KAREEM, I; ${ }^{2}$ AKINRINDE, EA; ${ }^{3}$ OLADOSU, Y; ${ }^{1}$ EIFEDIYI, EK ; ${ }^{4}$ ABDULMALIQ, \\ SY; ${ }^{1}$ ALASINRIN, SY; ${ }^{5}$ KAREEM, SA; ${ }^{1}$ ADEKOLA, OF \\ ${ }^{l}$ Department of Agronomy, University of Ilorin, P. M. B. 1515, Ilorin, Nigeria \\ ${ }^{2}$ Department of Agronomy, University of Ibadan, Ibadan, Nigeria \\ ${ }^{3}$ Institute of Tropical Agriculture, Universiti Putra Malaysia, 43400 Serdang, Selangor, Malaysia \\ ${ }^{4}$ Department of Crop Production, Ibrahim Badamasi Babangida Univesity, Lapai, Niger State, Nigeria \\ ${ }^{5}$ Department of Biology, School of Secondary Education (Science Programme), Federal College of Education (Special), Oyo, Nigeria. \\ *Corresponding Author Email: ishaaqabdulkareem@yahoo.com; Tel: +2348032454636
}

\begin{abstract}
The objective of this study was to evaluate the yield and quality of sweet potato under the influence inorganic fertilizer (NPK 15:15:15) at the recommended rate of $130 \mathrm{~kg} / \mathrm{ha}$, organic fertilizer (Pace Setter) at the recommended rate of 3t/ha and organo-mineral fertilizer (combination of NPK 15:15:15 and Pacesetter organic fertilizer) at the rate of $1.5 \mathrm{t} / \mathrm{ha}$. The fresh and dry weights of the samples were taken after which their proximate analyses were done to determine the levels of the quality determinants (moisture content, crude protein, ether extract, crude fibre, Vitamin A and ash content) in them. At the end of the experiment, harvesting was done to determine the yield per treatments as well as the quality parameters of the leaves and tubers. It was found that organic fertilizer could increase the quantity of ether extract, crude fibre and vitamin A contents of sweet potato tubers above other fertilizer treatments though organic fertilizer competed with the control in increasing the ash and crude protein contents of sweet potato tubers. However, inorganic fertilizer increased only energy content of the tubers above organic and organo-mineral fertilizer treatments. It is, therefore, concluded that organic fertilizer should be used to increase sweet potato tuber quantity and quality.
\end{abstract}

DOI: $\underline{\text { https://dx.doi.org/10.4314/jasem.v24i1.16 }}$

Copyright: Copyright (C) 2020 Kareem et al. This is an open access article distributed under the Creative Commons Attribution License (CCL), which permits unrestricted use, distribution, and reproduction in any medium, provided the original work is properly cited.

Dates: Received: 30 November 2019; Revised: 20 December 2019; Accepted: 23 December 2019

Keywords: Sweet potato, growth, yield, quality and fertilizer treatments

After wheat, rice, maize, Irish potato and barley comes sweet potato (Ipomoea batatas) as one of the important food crops in the world. This makes it come second (after Irish potato) in root and tuber production of the world and third position (after Irish potato and cassava) in consumption in many areas of tropical Africa (Lenne, 1991). Its ability to feed man is based on the fact that it has the highest solar fixing efficiency primarily because of its capacity to produce dry matter for a long time. Moreover, it is adaptable to tropical and subtropical climates, tolerant to drought and grows under marginal condition of low fertility and $\mathrm{pH}$. Over the last few decades, consumers' demand for healthier food and government policies which focused on environmentally sustainable agricultural systems have both promoted a rapid expansion of organic farming. In this regard, potato (Solanum tuberosum L.) represents a major food crop in many countries where the demand for organic products is gradually increasing. In line with this, it has become a widespread belief that organic farming improves the state of the environment, the health of people and the quality of food products (Woese et al., 1997). The assertion that organic agriculture produces healthy food is based on higher concentrations of beneficial secondary plant substances in organically grown crops compared to non- organically grown ones (Köpke, 2005). Despite this, the existence of differences in the nutritional value of organic and conventional food products remains a crucial question without definite answer till date (Bradt and Molgaard, 2001). Valid nutritional quality comparisons between organic and conventional foods require that the plants be cultivated in similar soils, under similar climatic conditions, sampling should be at the same time, pre-treatment should be similar and analysis should be by validated methods (Kumpulainen, 2001). Although organic foods are generally considered healthier than conventionally-grown ones, an improved nutritional profile of organic versus conventional crops has not been ascertained (Gennaro and Quaglia, 2003). Furthermore, it is not known whether different cultivation systems may affect the nutrient composition of the final produce. Consequent upon this, a clear link between cultivation system and nutritional value of agricultural products remains 
missing (Bourn and Prescott, 2002). Currently, research information about the differences in the quality of conventionally and ecologically cultivated potatoes is neither homogenous nor sufficient (Hamouz et al., 2005). Also, in the opinion of the experts, the present knowledge is not sufficient to conclude that organically grown foods would have a positive effect on health (Kessen, 2003). The Swiss Association for Research and Nutrition concluded that from a scientific viewpoint, organic foods are neither healthier nor safer than conventional products. Some studies have even shown that organically produced food may contain more fungal toxins that food produced by conventional methods (Bruulsema, 2002). In the same vein, many researchers have stated that organically grown crops contain fewer nitrates but higher concentrations of important nutritive substances (Worthington, 1998). Despite the report on slightly higher contents of minerals and trace elements in organically grown plants, the majority of evidence has revealed no significant differences among them (Warman and Havard, 1998). It is well established that high quality food can be produced using either organic or inorganic nutrient sources. If differences occur between crops produced with organic or inorganic fertilizers, they usually occur from differences in amount and balance of nutrients supplied (Bruulsema, 2002). To strengthen this fact,, a trial results has revealed that when the amount of basic nutrients (NPK) applied with organic and mineral fertilizers are equal, there will be no significant differences in the biological yield and quality of a crop (Järvan and Laitamm, 1998). The use of fertilizer in increasing the quality parameters of sweet potato is highly demanded. This is because if breeding programme is used, the same result could be obtained but it takes a lengthy period for a single breeding programme to go to completion except if marker assistance is employed. Despite the difficulty in getting any difference between organically or conventionally produced crops as highlighted above, the world is currently moving towards organic production of crops for the discovered and envisaged advantages. With this drive, farmers are still faced with the challenges of the bulkiness of organic fertilizer to be used and further gains that could be accrued from it if sacrifice of using it is made. Therefore, this work evaluated the effectiveness of organic, inorganic and organo-mineral fertilizers in improving yield and quality of sweet potato.

\section{MATERIALS AND METHODS}

This experiment was carried out at the Teaching and Research Farm, University of Ibadan, Oyo State (7.27 $\mathrm{N} 3.5^{\circ} \mathrm{E}$ ). The area had a mean temperature range between $22^{\circ} \mathrm{C}$ and $38^{\circ} \mathrm{C}$ and annual rainfall range of $1000 \mathrm{~mm}$ to $1600 \mathrm{~mm}$. The pre-cropping soil analysis revealed that the soil was acidic and the textural class was sandy-loam. The soil was low in carbon and nitrogen contents while potassium and phosphorus contents were within their critical ranges.

Vines of sweet potato (Shaba variety) were cut into $25 \mathrm{~cm}$ long pieces with at least two nodes per cutting for higher sprouting percentage to be achieved. The vine cuttings were planted on ridges with spacing of $30 \mathrm{~cm} \times 100 \mathrm{~cm}$ to give 33,333 plants per hectare. The vine cuttings were planted at an angle of $45^{\circ}$ to the soil with two thirds of the vine in the soil for proper establishment.

Four treatments were used in this experiment. Each treatment was replicated three times to have a total of twelve plots. The design of the experiment was Randomised Complete Block (RCB). The treatments were control (zero fertilizer), organic, inorganic and organo-mineral fertilizers. NPK 15:15:15 at the rate of $130 \mathrm{~kg} / \mathrm{ha}$ was used as inorganic fertilizer while fortified Pacesetter organic fertilizer at the rate of $3 \mathrm{t} / \mathrm{ha}$ was used as organic fertilizer. For organo-mineral fertilizer, it was compounded on the basis of nutrient composition from NPK 15:15:15(two parts) and Pacesetter organic fertilizer (one part). The application rate was $1.5 \mathrm{t} / \mathrm{ha}$. The treatments were applied four weeks after planting. Throughout the experiment, there was regular weeding of the experimental plots. Rouging was resorted to when vines had covered the ground to forestall injuring the plants.

At maturity (three months after planting), three representative plants were destructively sampled and partitioned into tubers, leaves and stems. The samples were then weighed fresh and dried to determine their moisture content. Proximate analysis was then carried out on the dried leaf and tuber samples to determine percentage dry matter, ash, crude protein, crude fat, crude fibre, energy and the amount of vitamin A present in the samples using AOAC (1984) method. Final harvesting was done when the leaves of the plants turned brown to determine the influence of the treatments on the tuberous yield. Finally, the collected data were analysed using Analysis of Variance (ANOVA) with the aid of Genstat 5 package while significant means were separated using Least Significant Difference (LSD) method at 5\% probability level.

\section{RESULTS AND DISCUSSION}

The highest moisture content from tubers was from inorganic fertilizer treated plants followed by organic fertilizer treated plants while the least was recorded from the control plants (Figure 1). The highest 
moisture percentage in the leaves of sweet potato was from inorganic fertilizer treated plants. This was followed by organic fertilizer plants while the least moisture content was from the control plants (Figure 2).

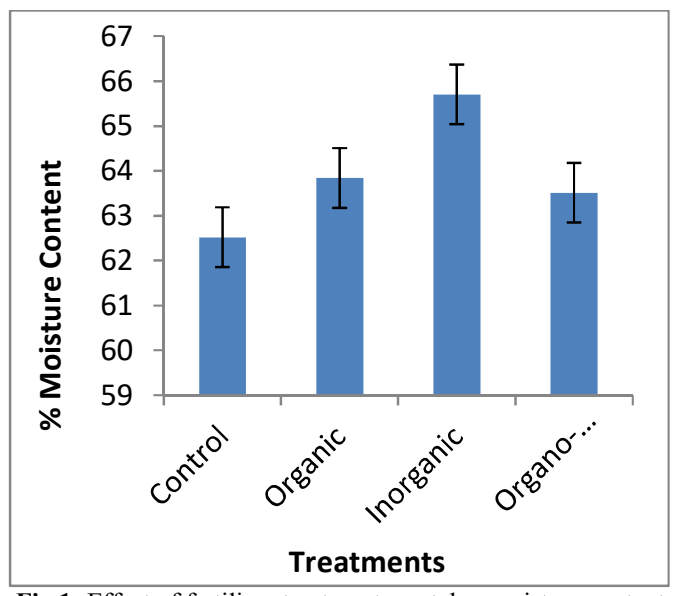

Fig 1: Effect of fertilizer treatments on tuber moisture content

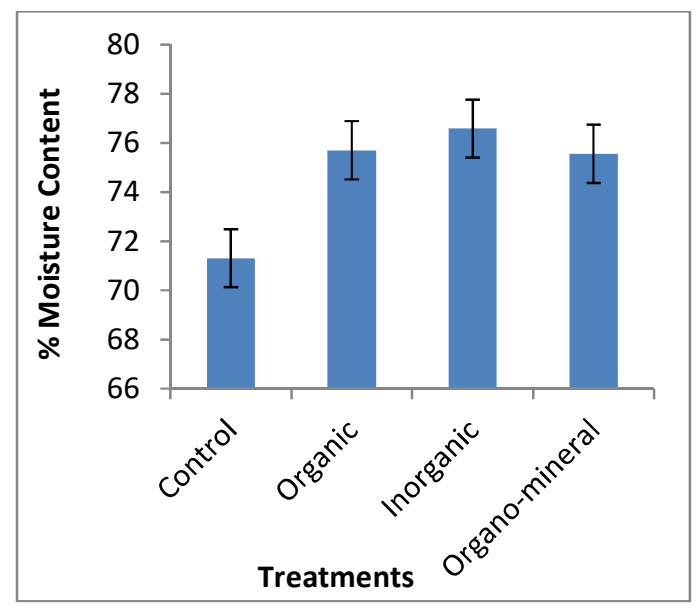

Fig 2: Effect of fertilizer treatments on leaf moisture content

This implies that moisture content of sweet potato could be increased by application of NPK fertilizer to sweet potato. However, this makes the tuber to be prone to disease attack. Moreover, the tubers will have short shelf lives because of high level of succulence. This is detrimental to storage of the tubers for a very long time and their carriage to a far distance for better sales when there is glut in the area of production.

The highest ash content in the tubers was from both the control and organic fertilizer treated plants followed by inorganic fertilizer treated plants while the least was from plants treated with organo-mineral fertilizer (Figure 3).
The highest leaf ash content was recorded from inorganic fertilizer treated plants followed by the control plants while the least was from organo-mineral fertilizer treated plants (Figure 4). The ash content signifies the level of minerals in the tuber.

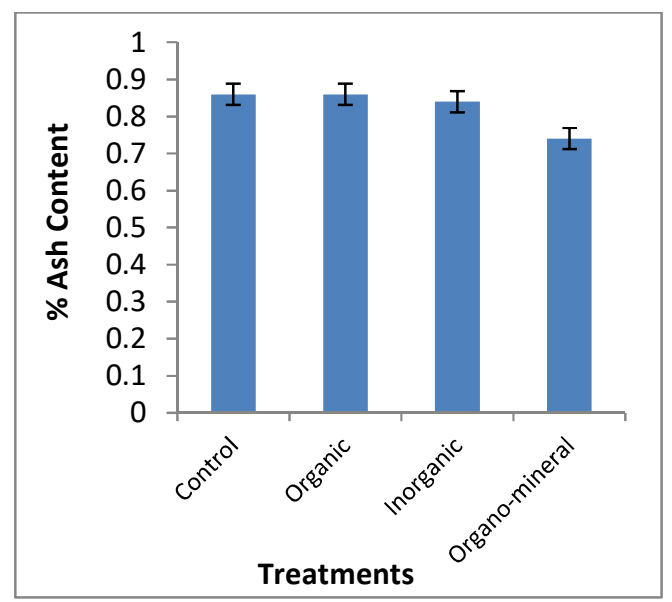

Fig 3: Effect of fertilizer treatments on tuber ash content

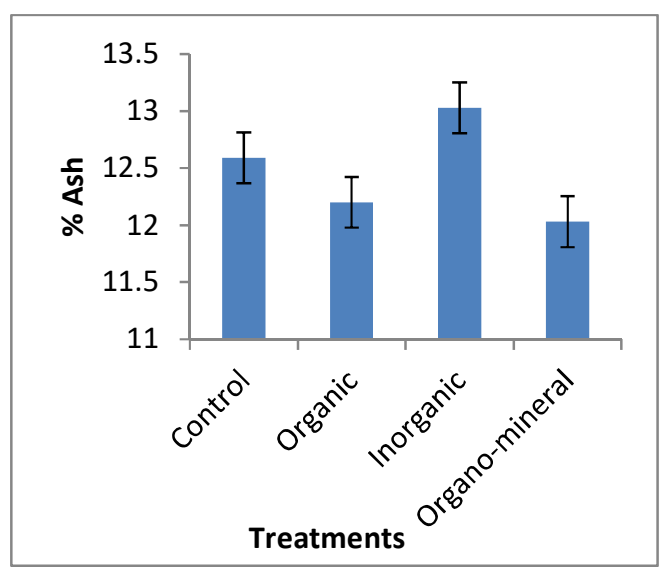

Fig 4: Effect of fertilizer treatments on leaf ash content

The improvement in the mineral nutrient resulting from application of organic fertilizer as well as no fertilizer application could be attributed to balance in soil nutrients which guaranteed even absorption of nutrients without antagonism as the case may be where inorganic fertilizer is involved. Furthermore, the case of plants treated with organic fertilizer is like that of the control because of very slow rate of release of nutrients in organic fertilizer. Furthermore, the case of plants treated with organic fertilizer is like that of the control because of very slow rate of release of nutrients in organic fertilizer. The highest crude protein percentage in tuber was from the control plants followed by organic fertilizer treated plants while 
inorganic fertilizer treated plants had the lowest percentage (Figure 5).In leaf crude protein production, the highest percentage was recorded from organomineral fertilizer treated plants followed by organic fertilizer treated plants while the lowest percentage was recorded from inorganic fertilizer treated plants (Figure 6). The highest level of crude protein found in tubers of plants treated with organic fertilizer might be the result of better nitrogen supply to the tubers. The fertilizer might have aided protein synthesis and prevented accumulation of amino acids. It can still be the result of decrease in the activities of hydrolysing enzymes which might have led to accumulation of amino acids at the expense of protein synthesis (Pessarakli andTucker, 1988). Furthermore, high protein content could have resulted from high nitrate reduction activity which led to increase in plant growth.

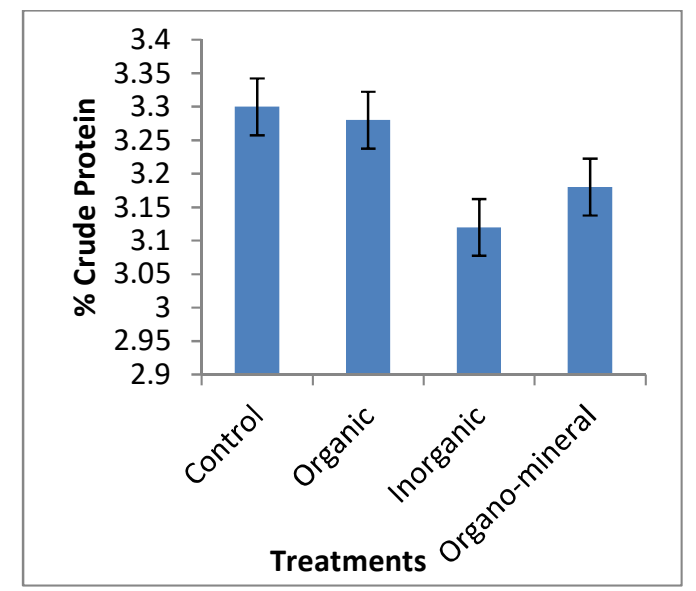

Fig 5: Effect of fertilizer treatments on tuber crude protein conten

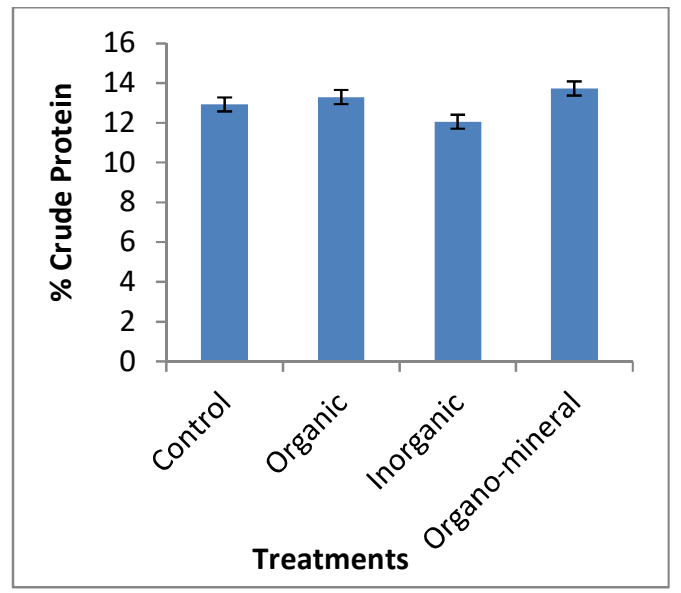

Fig 6: Effect of fertilizer treatments on leaf crude protein content

The highest percentage of ether extract in tubers was found from organic fertilizer treated plants followed by organo-mineral fertilizer while the least was from inorganic fertilizer treated plants (Figure 7). Ether extract content of the leaves was highest in inorganic fertilizer treated plants followed by the control plants while organo-mineral fertilizer treated plants had the least (Figure 8). Ether extract (crude fat) is an indicator of energy production (twice that of carbohydrate), means of absorption of fat soluble vitamins, protector of delicate organs in the body as well as insulator against cold. The use of organic fertilizer increased ether extract of the tubers above the control in this work. This supports the present clamour for organic farming that is currently gaining acceptance of all and sundry in crop production.

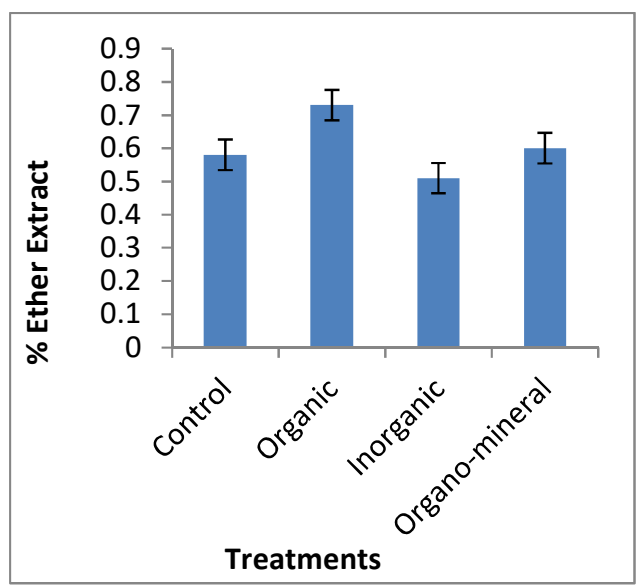

Fig 7: Effect of fertilizer treatments on tuber ether extracts content

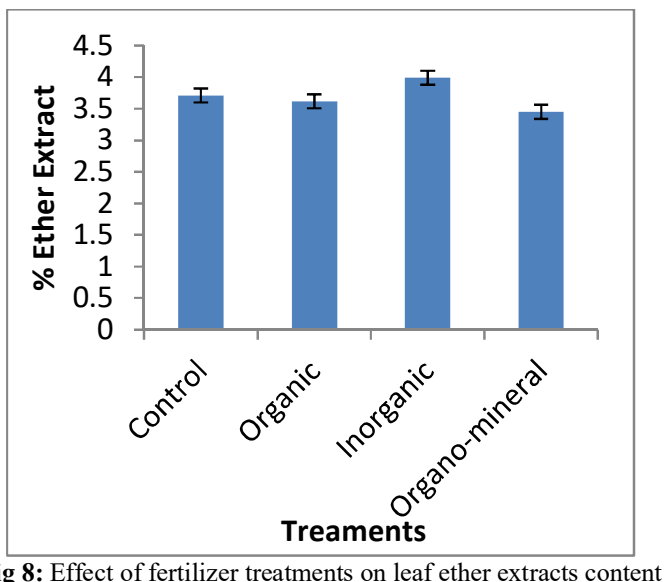

The highest crude fibre production was from the inorganic fertilizer treated plants followed by the control while organic and organo-mineral fertilizer treated plots had the lowest percentage (Figure 9). Crude fibre content of the leaves was at the peak in inorganic fertilizer treated plants. This was followed by the control plants while the least percentage was from organo-mineral fertilizer treated plants (Figure 10). Crude fibre is the part of an organic material (food 
or feed) that contains cellulose and other carbohydrates which are insoluble in either weak acid or alkali solution. High content of crude fibre implies low digestibility of the food or feed material as well as low energy and total digestible nutrient (TDN). The increase in crude fibre by of inorganic fertilizer implies that the tuber produced will be of low usefulness as either food or feed. So, the mechanism of tuber bulking from application of inorganic fertilizer is through increase in fibre content and water which are both disadvantages because they result in low shelf life, low dry matter content and low digestibility.

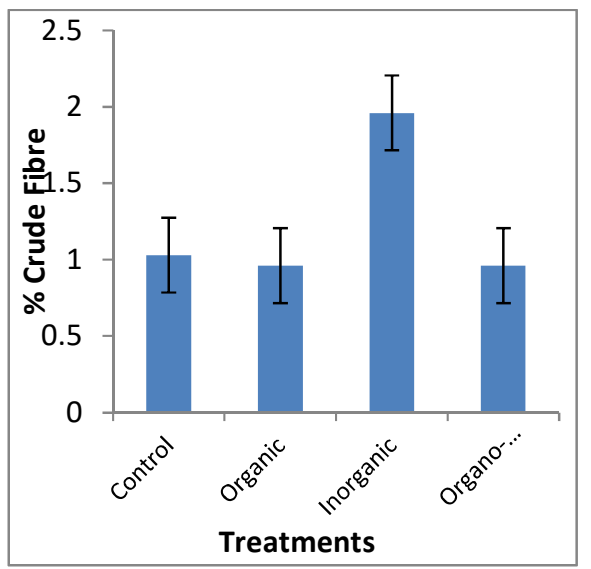

Fig 9: Effect of fertilizer treatments on tuber crude fibre content

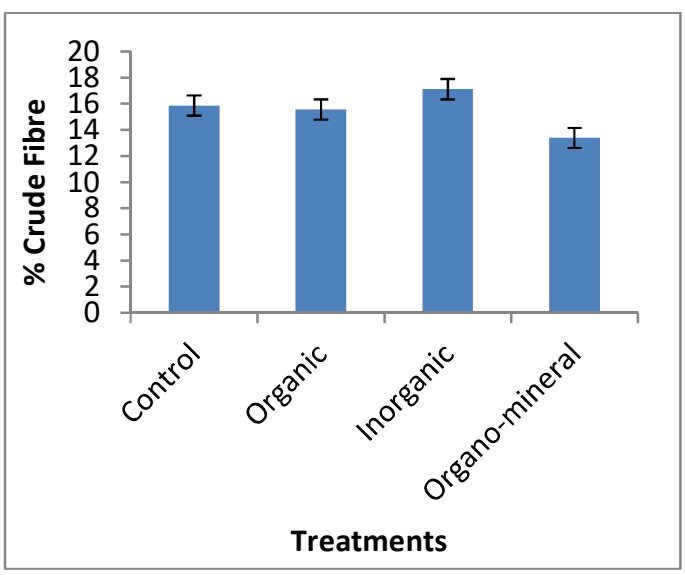

Fig 10: Effect of fertilizer treatments on leaf crude fibre content

However, the use of organic and organo-mineral fertilizers could guarantee low crude fibre content and the resultant high digestibility. Vitamin A production in tubers was highest in the plants treated with organic fertilizer followed by organo-mineral fertilizer treated plants while the least was from inorganic fertilizer treated plants (Figure 11). The highest leaf vitamin A production was from plants treated with organomineral fertilizer followed by organic fertilizer treated plants while the least vitamin A production was recorded from inorganic fertilizer treated plants (Figure 12). Vitamin A helps in formation and maintenance of healthy teeth, mucus membrane, soft and skeletal tissues as well as the skin. It is equally for promotion of good eye sight when light intensity is low. The use of organic fertilizer made the achievement of increase in vitamin A easy in sweet potato tubers. Even in the leaves, the organic fertilizer aided better production of Vitamin $\mathrm{A}$ in the organomineral-fertilizer used. This result could be linked to aiding of synthesis of beta-carotene which is a precursor of vitamin A synthesis. Furthermore, organic fertilizer might have been antagonistic to development of other competing pigments or compounds and it, therefore, paved the way for continuous production of carotene with eventual vitamin A production.

The highest energy content in sweet potato tubers was aided by inorganic fertilizer followed by organomineral fertilizer while no fertilizer treatment (control) resulted in lower energy status of the tubers (Figure 13). Leaf energy content was at its peak in plants treated with organic fertilizer followed by the control plants while the least energy content was from leaves of inorganic fertilizer treated plants (Figure 14).

The energy content of sweet potato tubers (derived from its carbohydrate contents) was higher than that of leaves.

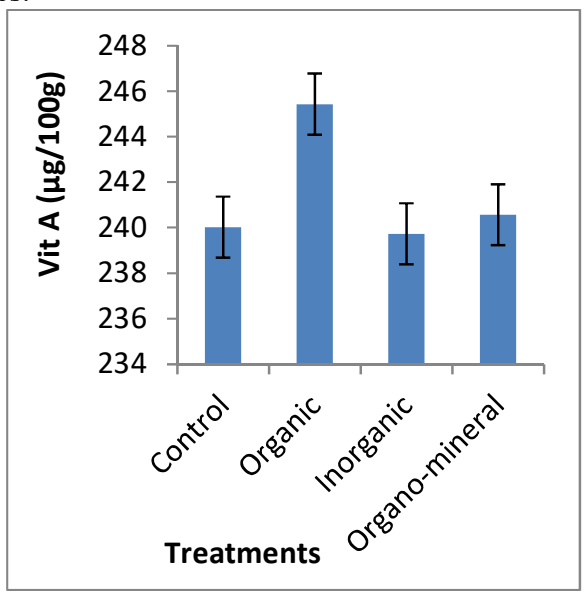

Fig 11: Effect of fertilizer treatments on tuber vitamin A content

Therefore, sweet potato tubers are often used as a source starch in industries to manufacture adhesives, dextrin, paper and as well as cosmetics ( $\mathrm{Lu}$ et al., 1989) because there is a link between energy level of the tubers and starch production. It is also for this same reason that sweet potato tubers are used industrially for producing glucose, syrup noodles and alcohol. 


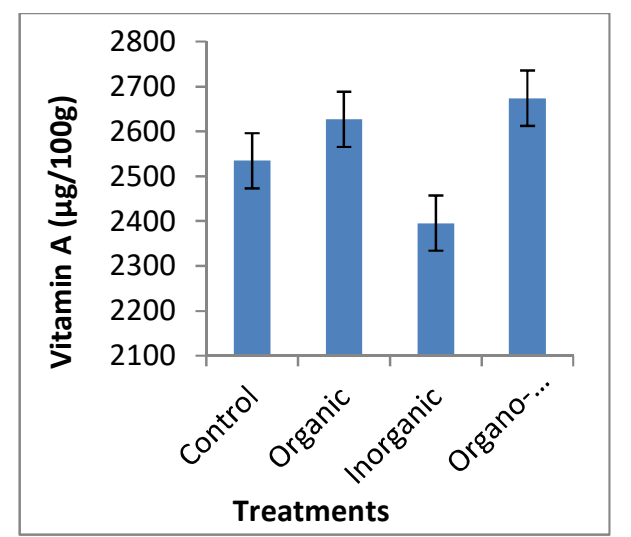

Fig 12: Effect of fertilizer treatments on leaf vitamin A content

Furthermore, these tubers can also be used as animal feed or infant food (Ambe, 1997). In the same vein, large quantities of sweet potato, mainly culls, are used in some countries as a high carbohydrate feeding stuff for cattle, pigs and poultry (Otoo et al., 2001) in addition to being used occasionally as food for Tilapia in fish ponds. The per cent dry matter yield in the tubers of sweet potato ranged from $34.30 \%$ to $37.48 \%$. The least dry matter production $(34.30 \%)$ was recorded from inorganic fertilizer treated plants while the highest $(37.48 \%)$ was realized from the control plants (Table 1).

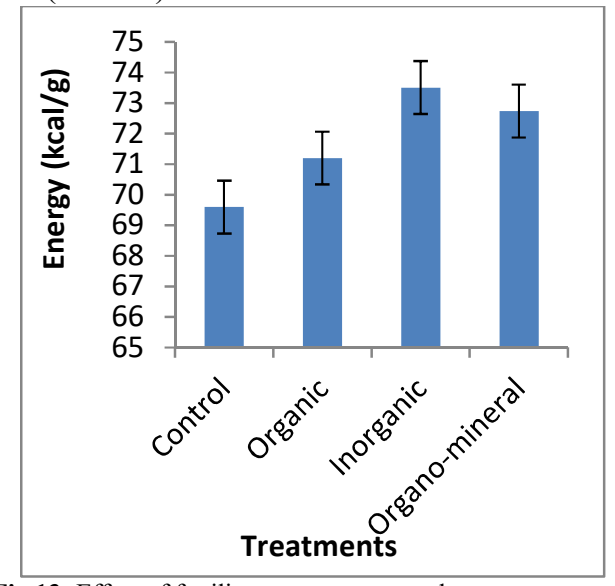

Fig 13: Effect of fertilizer treatments on tuber energy content

Leaf dry matter production ranged between $23.42 \%$ and $28.59 \%$. The highest $(28.59 \%$ ) was also produced by the control plants while the least dry matter $(23.42 \%)$ was still produced by plants treated with inorganic fertilizer (Table 1). The range of fresh tuber mass was from $5.43 \mathrm{t} /$ ha to $10.90 \mathrm{t} / \mathrm{ha}$. The lowest fresh mass $(5.43 \mathrm{t} / \mathrm{ha})$ was from the control while the highest $(10.90 \mathrm{t} / \mathrm{ha})$ was from the plants treated with organic fertilizer (Table 1). Fresh mass of leaves was between $0.99 \mathrm{t} / \mathrm{ha}$ and $1.07 \mathrm{t} / \mathrm{ha}$.

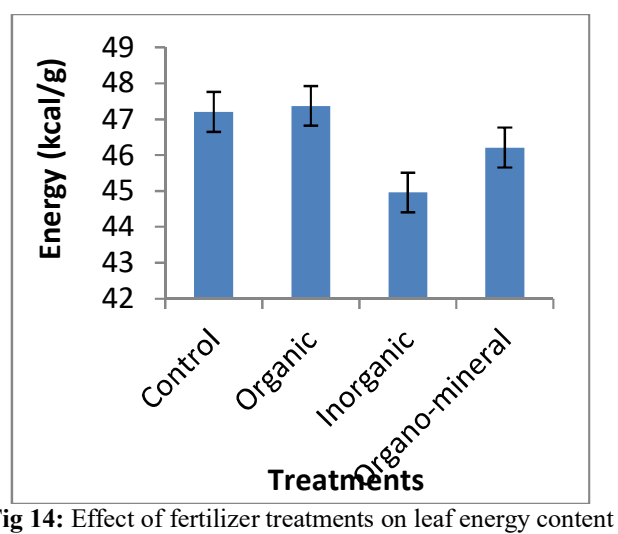

The lowest mass $(0.95 \mathrm{t} / \mathrm{ha})$ was from the control plants as well as organic fertilizer treated plants while the highest mass $(1.07 \mathrm{t} / \mathrm{ha})$ was from organic fertilizer treated plants (Table 1). The dry matter production was high in the leaves of plants from the control plots because the fertilizer treated plots had higher moisture contents than found in the control plots (Figure 2). The same reason is advanced for dry matter production in tubers (Figure 1). These results further establish a well-known fact that when root or stem tubers are aided with fertilizers, the moisture content of the tubers increases. However, per cent dry matter production in the leaves was less than that of tuberous roots. This could be attributed to the fact that accumulation of dry matter in vines and tuberous roots is on the increase throughout the growing period (Ramanujam and Indira, 1985) as against that of leaves which ceases as senescence sets in. Furthermore, the rate of dry matter (DM) production and its partitioning varies greatly during the growing period. The ratio of root to shoot increases up to 60 days after planting and, therefore, the dry matter accumulation in tuber exceeds that of the shoot (vine and leaves) with the commencement of tuber bulking. The implication is that while there is decrease in vine mass towards harvest, the tuber mass increases linearly with the age of crop. The highest tuber production found from the plots treated with inorganic fertilizer could be linked to high potassium content of the inorganic fertilizer used. The work of potassium in this situation is that it accelerates translocation of photosynthates from leaves to tubers by increasing its photosynthetic efficiency. This becomes more obvious in the fact that when potassium becomes limiting, yield of sweet potato becomes significantly suppressed (FAO (1990). Furthermore, high $\mathrm{K}$ levels results in higher root yield by increasing leaf area duration and suppressing excessive leaf growth. Finally, the key factors to increased sweet potato yield are the careful regulation of $\mathrm{N}$ levels and liberal supply of $\mathrm{K}$ to increase sink capacity and photosynthesis. 
Table1: Influence of different fertilizer types on sweet potato yield traits

\begin{tabular}{lllll}
\hline Fertilizer & $\begin{array}{l}\text { Tuber Dry } \\
\text { Matter } \mathbf{( \% )}\end{array}$ & $\begin{array}{l}\text { Leaf Dry } \\
\text { Matter } \mathbf{( \% )}\end{array}$ & $\begin{array}{l}\text { Fresh Tuber } \\
\text { Yield (t/ha) }\end{array}$ & $\begin{array}{l}\text { Fresh Leaf } \\
\text { Yield (t/ha) }\end{array}$ \\
\hline Control & 37.48 & 28.59 & 5.43 & 0.99 \\
Organic & 36.15 & 24.30 & 8.76 & 1.07 \\
Inorganic & 34.30 & 23.42 & 10.9 & 1.06 \\
Organo-mineral & 36.39 & 25.28 & 7.90 & 0.95 \\
Lsd & ns & ns & 3.47 & ns \\
\hline
\end{tabular}

Finally, it should be noted from this work that the magnitude of quality traits in the leaves of sweet potato with or without fertilizer treatment was higher than what the tubers produced. This implies that the leaves of sweet potato are more nutritious than the tubers. This fact is relied upon by people who use sweet potato foliage as vegetable as it is eaten in some parts of Africa and Philippines.

Conclusion: It is evident from the results of this experiment that organic fertilizer could increase the quantity of ether extract, crude fibre and vitamin A contents of sweet potato tubers above other fertilizer treatments though organic fertilizer competed with the control in increasing the ash and crude protein contents of sweet potato tubers. It is, therefore, concluded that organic fertilizer should be used to increase of sweet potato tuber quantity and quality.

\section{REFERENCES}

Ambe, J T (1997). Response of sweet potato (Ipomoea batatas) to seedbed preparation in high rainfall forest zone of Cameroon. Afr. J. Root and Tuber Crops 3(1): 22-23

AOAC (1984). Official method of the analysis of the association of the official analytical chemist. $12^{\text {th }}$ Edition, Washington DC.

Bourn, D; Prescott, J (2002). A comparison of the nutritional value, sensory qualities, and food safety of organically and conventionally produced foods. Crit. Rev. Food Sci. Nutr. 42, 1-34

Brandt, K; Molgaard, J P (2001). Organic agriculture: does it enhance or reduce the nutritional value of plant foods? J. Sci. Food Agric. 81, 924-931.

Bruulsema, T W (2002). Fertilizing for quality. In: Proceedings of the Eastern Canada Agronomy Workshop, Cornwall, Ontario, Canadian Fertilizer Institute, 1-9.

FAO (1990). Rots, tubers, plantains and bananas in human nutrition. Food and Agricultural Organization (FAO). Food and Nutrition Series. No 24. 182p
Gennaro, L; Quaglia, G (2003). Food safety and nutritional quality of organic vegetables. Acta Horticulturae 61, 675-680.

Hamouz, K; Lachman, J; Dvořák, P; Pivec, V (2005). The effect of ecological growing on the potatoes yield and quality. Plant Soil Environ. 51, 9, 397402.

Järvan, M; Laitamm, H (1998). Effect of Cultivation Method on the Yield and Biological Quality of Garden Crops, and on the Microbiological Processes in Soil. Transactions of the Estonian Academic Agricultural Society, 6, Tartu, 19-22.

Kessen, R (2003). Öko-Lebensmittel nicht generell gesunder. Gemüse, 8, 40-41

Köpke U (2005). Organic Foods: Do They Have a Role? In Elmadfa, I. (ed.): Diet Diversification and Health Promotion. Forum Nutr. Basel, Karger AG, Vol. 57, 62-72

Kumpulainen, J (2001). Organic and conventional grown food stuffs: Nutritional and toxicological quality comparisons. Proc. Int. Fert. Soc. 472, 120

Lenne, JM (1991). Diseases and pests of sweet potato: South East Asia, the pacific and east Africa. Natural Resources Institutes. Bulletin 46(7):116

Lu, SY; Xue, Q H; Zhang, O P; Song, B F (1989). Sweet potato production and research in China. In: Improvement of sweet potato (Ipomoea batatas) in Asia. Report of the "Workshop on sweet potato improvement in Asia". ICAR, India, Oct. 24-28, 1988

Otoo, J A; Misah, A; Carson, A G (2001). Evaluation of sweet potato for early maturity across different agroecological zones in Ghana. Afr. J. Crop Sci. 9(1): 25-31

Ramanujam, T; Indira P (1985). Leaf area index, net assimilation rate and crop growth rate of five sweet potato genotypes. Proc. National Symp. On Production and Utilization of Tropical Tuber Crops. Nov. CTCRI, Trivadrum, India 
Pessarakli, M; Tucker, TC (1988).Dry matter yield and nitrogen-15uptake by tomatoes under sodiumchloride stress. Soil Sci. Soc. Am. J., 52(3): 698-700

Warman, P R; Havard, K A (1998). Yield, vitamin and mineral contents of organically and conventionally grown potatoes and sweet corn. Agric. Ecosyst. Environ. 68, 207-216
Woese, K; Lange, D; Boess, C; Bogl, K W (1997). A comparison of organically and conventionally grown foods - Results of a review of relevant literature. J. Sci. Food Agric. 74, 281-293

Worthington, V (1998). Effect of agricultural methods on nutritional quality: a comparison of organic with conventional crops. Altern. Ther. Health Med. 4, 58-69 